\title{
CALleREbIA Dibangensis (LePIDOPTERA: NyMPHALIDAE: SATYRINAE), A NEW BUTTERFLY SPECIES FROM THE EASTERN HIMALAYA, INDIA
}

\section{Purnendu Roy}

${ }^{1}$ Gabriel's Wharf, 56 Upper Ground, London SE1 9PP, UK

${ }^{1}$ purnendu@ganesha.co.uk

Abstract: A new species of butterfly in the genus Callerebia (Butler, 1867) is described from the Upper Dibang Valley district, Arunachal Pradesh, India. A combination of very distinctive characters: large size; highly rounded wings; striking under hindwing white scales; distinctive under hindwing tornal ocelli; large round forewing orange apical spot and a dark brown under ground colour distinguishes this butterfly from any other Callerebia species.

Keywords: Arunachal Pradesh, Callerebia opima, C. scanda, C. orixa, C. annada, C. suroia, Dibang Valley, Mithun River.

DOI: http://dx.doi.org/10.11609/JoTT.03293.4725-33 | ZooBank: urn:Isid:zoobank.org:pub:CA33D1C9-AD1B-4CE6-8C33-CBCEDEB81D29

Manuscript details: Ms \# 03293 | Received 06 August 2012 | Final received 12 September 2013 | Finally accepted 13 September 2013

Citation: Roy, P. (2013). Callerebia dibangensis (Lepidoptera: Nymphalidae: Satyrinae), a new butterfly species from the eastern Himalaya, India. Journal of Threatened Taxa 5(13): 4725-4733; http://dx.doi.org/10.11609/JoTT.03293.4725-33

Copyright: (C) Roy 2013. Creative Commons Attribution 3.0 Unported License. JoTT allows unrestricted use of this article in any medium, reproduction and distribution by providing adequate credit to the authors and the source of publication.

Funding: Self funded.

Competing Interest: Author declare no competing interest.

Author Details: PURNENDU ROY is a naturalist with a particular interest in the eastern Himalaya where he has recorded several new Indian butterfly records. He is currently working as a volunteer with Ifoundbutterflies.org developing the database and source code and is committed to open access resources for naturalists.

Acknowledgements: Dr. David Lees, Curator - Lepidoptera, Natural History Museum for his valuable views and assistance. Tipa Umbrey who guided me on many occasions in the Dibang Valley. Dibang Valley Political officer who also guided me several times. The many people of the Dibang Valley who provided me hospitality throughout my stay. Sanjay Sondhi, Titli Trust for giving me the opportunity to renew my passion for butterflies. Jo Lawbuary my partner for her love and support. 


\section{INTRODUCTION}

Callerebia (Butler, 1867) is a genus of approximately 11 species and 20 subspecies (Appendix 1), almost entirely confined to the Sino-Himalayan region. The genus is composed of medium to large butterflies with small bodies in relation to their broad, rounded wings. The hindwing in many species is produced at the tornus to form a slight lobe. The antennae are thin, only slightly thickening towards the tip. The markings, though very variable follow a fairly constant arrangement: the upper ground colour is dark brown to blackish; the forewing with a bi-pupilled apical ocellus; the upper hindwing with or without one tornal spot; the under hindwings are often covered by whitish scales of different densities, tones and patterns, with or without one or two tornal ocelli; in addition, some species have a set of up to four post-discal white dots on the under hindwing. All species may also have additional ocelli as part of their variation. Older literature on Indian butterflies (Talbot
1947; Wynter-Blyth 1957) places Callerebia under Erebia. Bruna et al. (2000) treat these species as being under Callerebia, Hemadara and Paralasa. Huang (2003) described a new species of Callerebia - C. ulfi from northwestern Yunnan and did a revision of $C$. polyphemus and its subspecies and had a note on the status of C. suroia. Bruna et al. (2000) comments on the taxonomic uncertainty of this genus, the remarkable variation in wing pattern and genitalia morphology. It is certainly the case that the variation in pattern that exists between different populations has made the use of key-based identification very difficult and has led to confusion over the status and identity of certain species and forms. Several of the eastern Himalayan species are characterised by their large orange-ringed forewing apical ocellus contrasting prominently against a dark brown, blackish upper ground colour. The under hindwings are covered with prominent white striations. Though many of the species appear confusingly similar, this new species is visually very distinct and is a beautiful

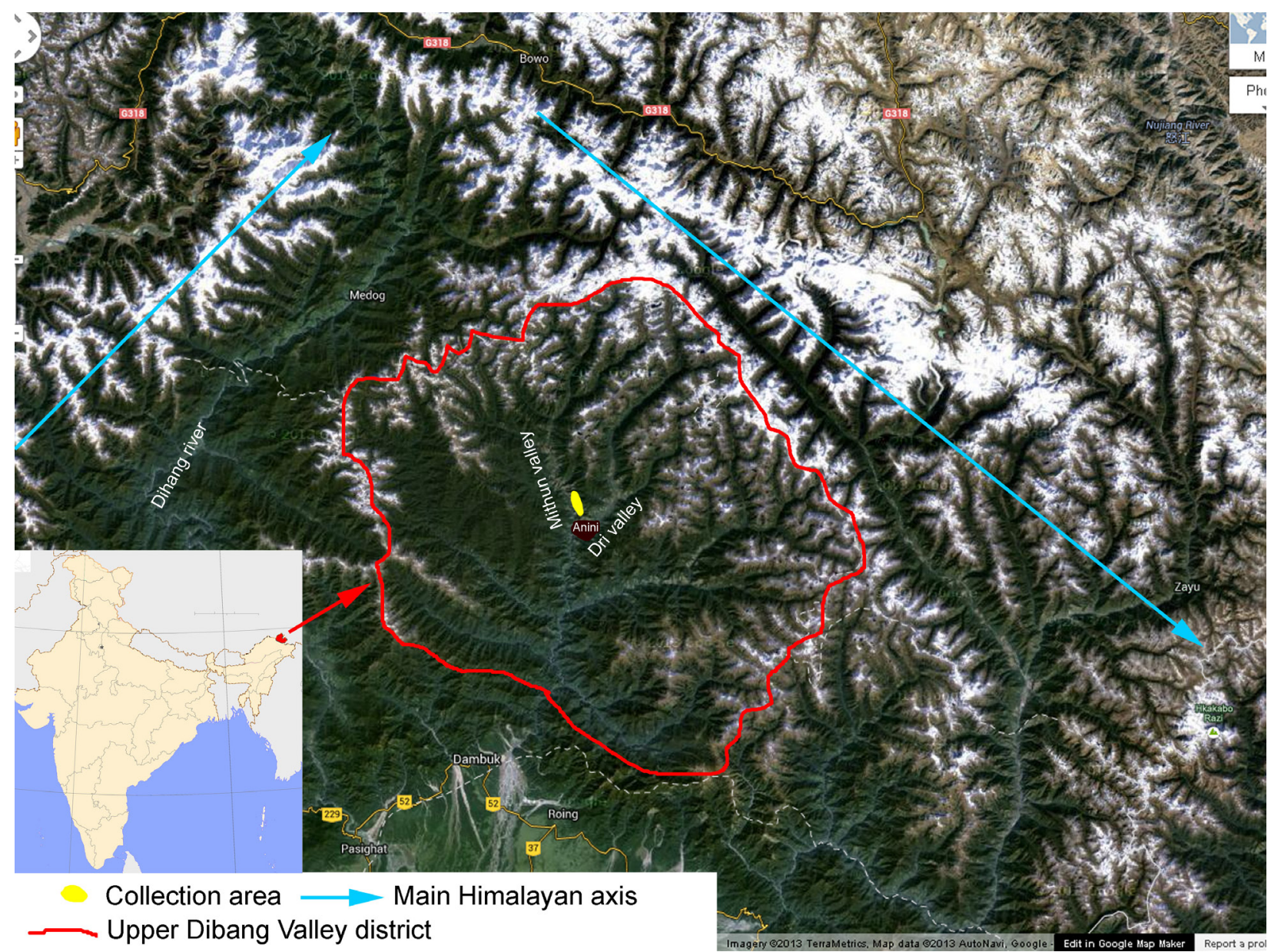

Figure 1. Satellite picture of Upper Dibang Valley District 
and striking addition to the eastern Himalayan fauna.

The Upper Dibang Valley District (Fig. 1) lies between $95^{\circ} 15^{\prime}-96^{\circ} 35^{\prime} \mathrm{E} \& 28^{\circ} 22^{\prime}-29^{\circ} 27^{\prime} \mathrm{N}$. It is further north than Bhutan, Sikkim and eastern Nepal. It is situated in a very complex and active geological zone where the main Himalayan axis turns abruptly north-west to south-east forming a ridge of moderately high mountains to the north and east, between 4000-5400 m, which separate the Dibang Valley from the Pemako region of Tibet to the north and Chayu county of Tibet to the east. A western ridge largely above $3600 \mathrm{~m}$ separates the Dihang and Dibang valleys. The district capital Anini $(1,968 \mathrm{~m})$ is situated on a plateau between the confluence of the Dri and Mithun rivers and its annual rainfall (2003) was 3,281.33mm (Upper Dibang Valley official website 2012). The predominant natural vegetation around $1800 \mathrm{~m}$ is sub-tropical hill forest and temperate forest. However, there are quite large areas of grasslands in the Dri and Mithun valleys probably formed principally by human activity. The district is sometimes regarded as India's remotest, on account that the road connection is frequently closed by landslides from April to October. $\mathbf{7 2 . 3 2 \%}$ of the district is recorded as forested (Department of Environment and Forests, Government of Arunachal 2012) and has the lowest population density of any district in India $\left(<1 \mathrm{~km}^{-2}\right)$ (Upper Dibang Valley official website 2012) (Fig. 1 - Satellite Image of Upper Dibang Valley District).

\section{METHOD AND MATERIALS}

The majority of the sites visited were in the Dri and Mithun valleys within a day's return walk from Anini (c. 2,000m) from the period of 17 July to 13 August 1987. 14 to 16 August 1987 were spent travelling to the Ithun Valley on the southern edge of the Upper Dibang Valley District. The Dibang Valley government provided a guide and assistance, which was invaluable. Only species considered of interest and which could not be determined in the field were collected. These are deposited in the Natural History Museum, London, U.K.

Previous to the visit to the Upper Dibang Valley, the author had undertaken numerous visits to Nagaland, Manipur and Arunachal Pradesh and so was familiar with many of the butterfly species that commonly occur in northeastern India.

\section{Callerebia dibangensis sp. nov. (Image 1)}

urn:Isid:zoobank.org:act:E75C7E6D-3C75-4AF5-853F-C9981CD51C53

\section{Material examined}

Holotype: \# 982926, 24.vii.1987, male, $28.88^{\circ} \mathrm{N} \&$ $95.85^{\circ} \mathrm{E}, \pm 10 \mathrm{~km}, \mathrm{c} .1,830 \mathrm{~m}$, Mithun Valley, Upper Dibang Valley District, Arunachal Pradesh, India, coll. Purnendu Roy, The Natural History Museum, London.

\section{Diagnosis}

There does not appear to be any other species of Callerebia like this species in the Natural History Museum collection.

The following is a list of characteristics that are unique to this specimen and/or rarely expressed by other Callerebia species. Reference can also be made to images 2-4 which feature the other Indian Eastern Himalayan species C. scanda opima, C. suroia, C. scanda scanda, C. orixa and C. annada annada. A Chinese species, $C$.

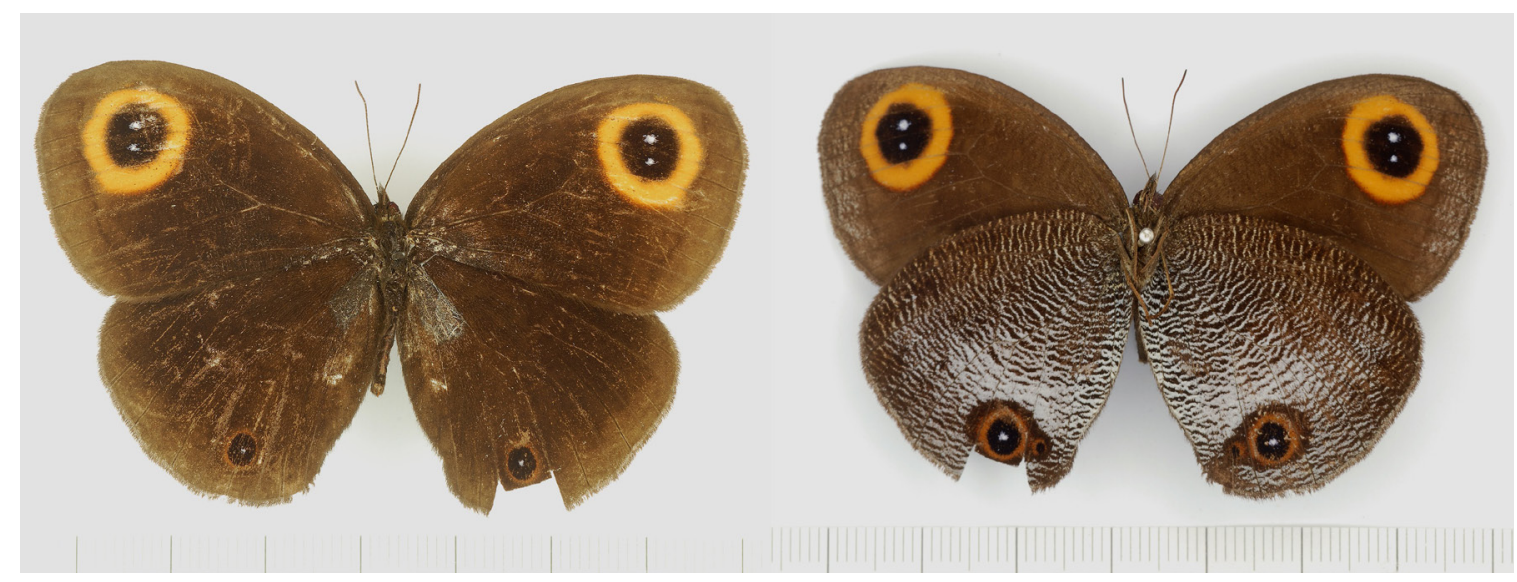

Image 1. Callerebia dibangensis sp. nov., male (holotype \# 982926) left dorsal view and right ventral view. c. 1,830m, 24.vii.1987, Mithun Valley, Upper Dibang Valley, Arunachal Pradesh, India. (c) Trustees of the Natural History Museum, London, used with permission 


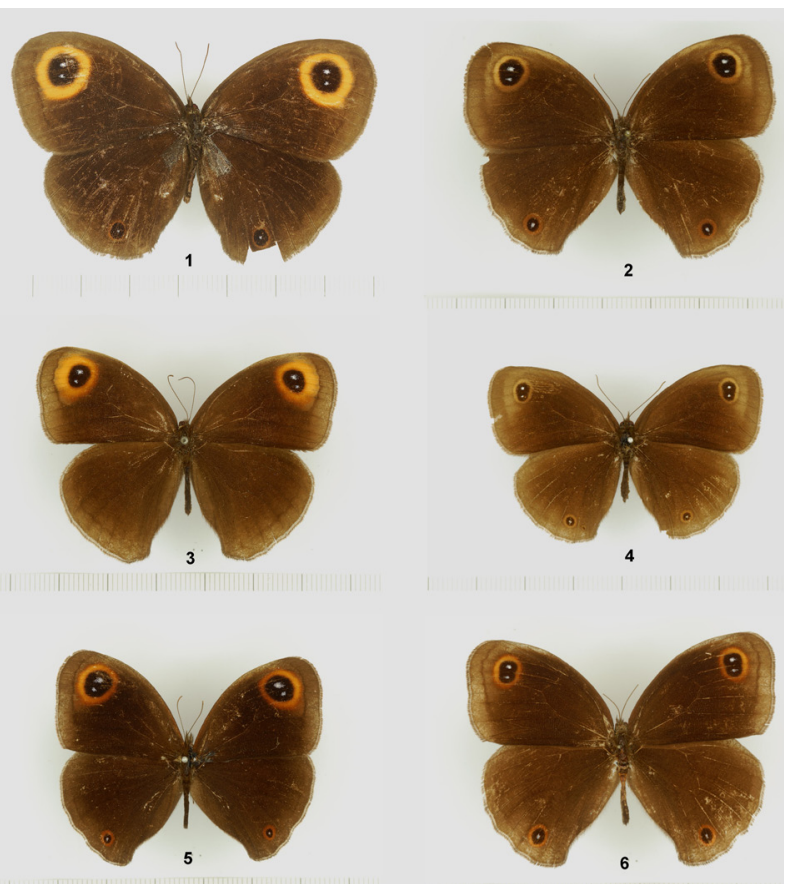

Image 2. Callerebia species from northeastern India - male dorsal view

1. C. dibangensis sp. nov., (holotype \# 982926) c.1,830m, 24.vii.1987, Mithun Valley, Upper Dibang Valley, Arunachal Pradesh, India; 2. C. scanda opima, 2,438-4,877 m, Lachin Lachoong, Sikkim, India; 3. C. suroria, $2,590 \mathrm{~m}$, Suroifui, Manipur, India; 4. C. scanda scanda, Darjeeling, West Bengal, India; 5. C. orixa, 03.x.1910, 1219m, Kohima, Nagaland, India; 6. C. annada annada, Bhutan (C) Trustees of the Natural History Museum, London, used with permission

polyphemus, is similar to $C$. suroia, but is usually not so well marked on the under hindwing. Comparison has only been made against male specimens. Females are usually larger, upper ground colour paler, underside markings more pronounced and the apical ocellus rounder.

(i) Size: One of the largest male Callerebia specimens (Table 3); only large forms of $C$. polyphemus and $C$. scanda opima are of comparable size. Within the NHM collection, $C$. dibangensis sp. nov. is noticeably larger than other male specimens.

(ii) Wing shape: The forewings are very large and broad, the costa convex and forming a smooth curve all around the apex to the termen. The hindwing tornus is barely produced and rather round. Only specimens of C. scanda opima from eastern Bhutan express a similar forewing shape, but their hindwing tornus tends to be noticeably produced.

(iii) Underside hindwing pattern: The under hindwing patterns of Callerebia (Image 4) are complex and difficult to describe. In several species the scales on the hindwing are arranged as short little white lines

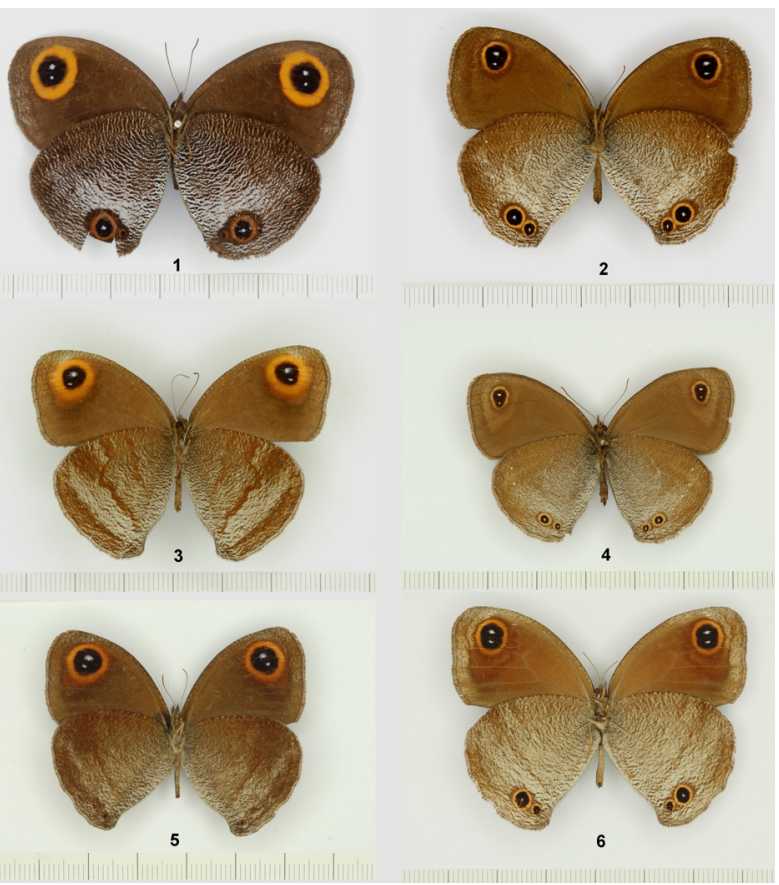

Image 3. Callerebia species from northeastern India - male ventral view

1. C. dibangensis sp. nov., (holotype \# 982926) c.1,830m, 24.vii.1987, Mithun Valley, Upper Dibang Valley, Arunachal Pradesh, India; 2. C. scanda opima, 2,438-4,877 m, Lachin Lachoong, Sikkim, India; 3. C. suroria, $2,590 \mathrm{~m}$, Suroifui, Manipur, India; 4. C. scanda scanda, Darjeeling, West Bengal, India; 5. C. orixa, 03.x.1910, 1219m, Kohima, Nagaland, India; 6. C. annada annada, Bhutan (C) Trustees of the Natural History Museum, London, used with permission

called striae. In the new species the white striae on the basal half of the wing are very well separated, regular and straight. They contrast prominently with the dark brown ground colour. Apart from the costal margin and apex the striae are always white with no evidence of variegation or bands in the hindwing pattern. The tone of the white scales is slightly violaceous.

(iv) Underside hindwing tornal ocelli: The ocellus in space 2 is larger than is typical for Callerebia and the ocellus in $1 \mathrm{c}$ tiny and blind. It is the only species where the ring colour is orange rather then yellowfulvous. When ocelli are expressed in other species this combination of a large ocellus in space 2, with a tiny blind ocellus in 1c, does not appear typical.

(v) Forewing apical ocellus: The ocellus is very large, rather round and has a wide and fairly regular orange ring of a uniform colour. C. suroia and C. polyphemus also have a large ocellus, but it is very different from the new species: when large the ring is constrained distally; far more irregular; elongated posteriorly and with a greater amount of red suffusion. The ocellus of C. orixa is the most similar in terms of appearance and 


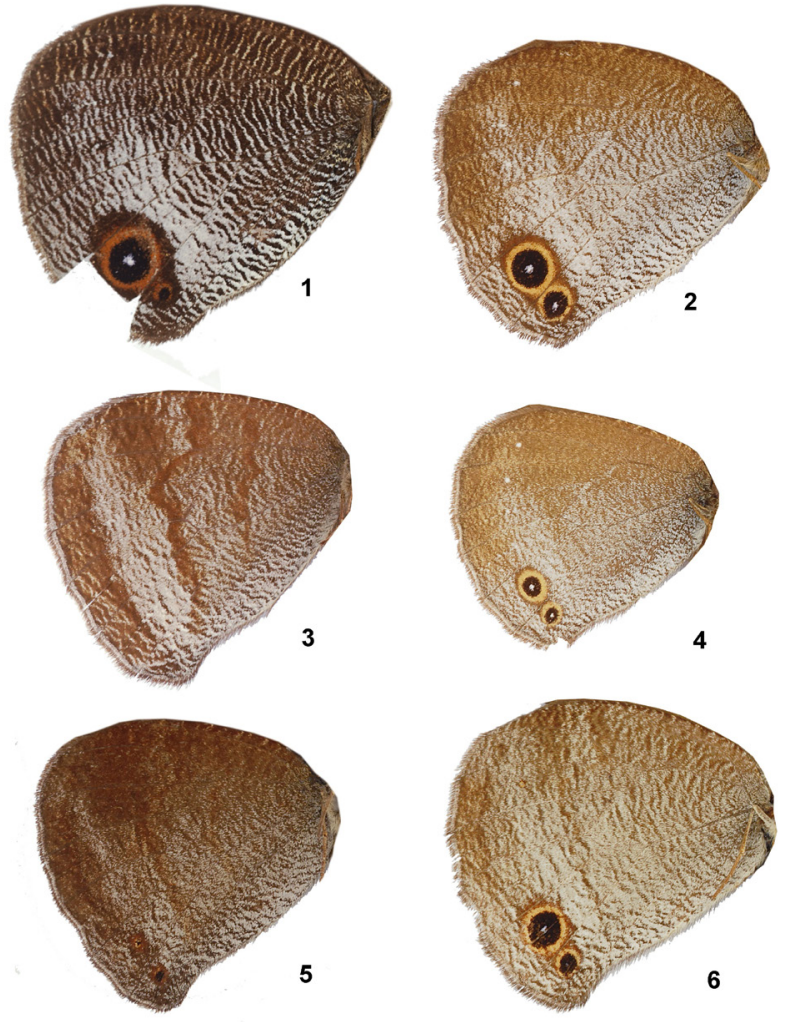

Image 4. Callerebia species from northeastern India - male hindwing ventral view

1. C. dibangensis sp. nov., (holotype \# 982926) c.1,830m,

24.vii.1987, Mithun Valley, Upper Dibang Valley, Arunachal Pradesh, India.

2. C. scanda opima, $2,438-4,877 \mathrm{~m}$, Lachin Lachoong, Sikkim, India

3. C. suroria, $2,590 \mathrm{~m}$, Suroifui, Manipur, India

4. C. scanda scanda, Darjeeling, West Bengal, India

5. C. orixa, 03.x.1910, 1219m, Kohima, Nagaland, India

6. C. annada annada, Bhutan

(C) Trustees of the Natural History Museum, London, used with permission

roundness, but the orange ring is never as wide as the new species in relation to ocellus size.

(vi) Under ground colour: Dark chocolate brown, much darker and plainer then $C$. scanda, C. orixa, $C$. suroia and C. annada.

The closest species appears to be $C$. scanda opima (Images 2-4, Fig. 2). Fourteen males of C. scanda opima in the NHM collection were compared with $C$. dibangensis sp. nov. and the key external features are summarised in Table 1.

Table 2 is a list of all Callerebia species with their key characteristics. It has been highlighted where they differ from $C$. dibangensis sp. nov. either as a group or individually.

Species names and genera were referenced in LepIndex (Beccaloni et al. 2003) and Savela (2012) to ensure that I have compared the new species with all possible species of Callerebia. There was no comparable species in the allied genera of Hemadara, Loxerebia, Argestina and Paralasa which are comprehensively covered by Bruna et al. (2000). The plates of d'Abrera $(1985,1990,1992)$ covering Satyrinae in the Holarctic and Oriental regions were also referred to and there appears to be no other genera this species may belong to.

On the basis of the unique combination of these characteristics mentioned above I propose this as a new species.

\section{Description}

Holotype: \# 982926, 24.vii.1987, male (Image 1). Forewing length $34 \mathrm{~mm} .28 .88^{\circ} \mathrm{N} \& 95.85^{\circ} \mathrm{E} \pm 10 \mathrm{~km}$, c.1,830m, Mithun Valley, Upper Dibang Valley District, Arunachal Pradesh, India, coll. Purnendu Roy, the Natural History Museum, London.

Upperside: Ground colour dark chocolate brown, slightly blackish, paler towards margins. Very large round orange-ringed apical ocellus $(11 \mathrm{~mm})$, black inner with two white pupils. Edges of ring distinct and regular. Hindwing single tornal ocellus in space 2. Narrow reddish ring, black inner and white pupil.

Underside: Ground colour dark chocolate. Forewing apical ocellus large as on upperside, but with an additional thin reddish outer ring. Forewing termen margin covered with a thin scattering of white scales tapering towards tornus. Hindwing white scales forming prominent small lines (striae) with slight violet tones covering the whole wing apart from a narrow area around the tornal ocelli. Striae become darker towards the costa and apex giving a fading effect. In the basal half they are more separate and alternate with the dark brown ground colour producing a distinctive snow-drift like appearance. They are densest towards the discal region in spaces 1, 2 and 3 where they merge with one another. Hindwing two tornal ocelli, ocellus in space 2 much larger then $1 c$ which is blind. Both ocelli orangeringed with a black centre. Ocellus in space 2 with a white pupil.

\section{Etymology}

Named after the Dibang Valley District in Arunachal Pradesh, India.

\section{Location}

Only one specimen was observed and collected on the 27 July 1987 and is the holotype. The species was collected along the track that leads from Anini to Mipi between the altitude of 1600-1800 m approximately 
Table 1. Comparison of Callerebia dibangensis sp. nov and C. scanda opima

\begin{tabular}{|c|c|c|}
\hline & $\begin{array}{l}\text { Callerebia dibangensis sp. nov., male } \\
\text { (Images 2-4, fig. 1) }\end{array}$ & $\begin{array}{l}\text { C. scanda opima, male } \\
\text { (Images 2-4) }\end{array}$ \\
\hline $\mathrm{f} / \mathrm{w}$ length $(\mathrm{mm})$ & 34 & 29 \\
\hline wing shape & $\begin{array}{l}\mathrm{f} / \mathrm{w} \text { costa, apex and termen rounded producing a very broad } \\
\text { and round wing. Ratio of height to width approx.0.76. }\end{array}$ & $\begin{array}{l}\text { Less rounded. Termen more inwardly facing. Wing less broad. Ratio } \\
\text { of height to width approx.0.67. }\end{array}$ \\
\hline \multicolumn{3}{|l|}{ Upperside } \\
\hline $\mathrm{f} / \mathrm{w}$ ground colour & $\begin{array}{l}\text { Dark chocolate brown. Blackish. } \\
\text { Paler on whole termen margin and apical region. Lacks the } \\
\text { alternating contrasting area distal to apical ocellus that is } \\
\text { typical in opima. Obscure dark submarginal band. }\end{array}$ & $\begin{array}{l}\text { Usually paler. Paler on termen margin between v1 to v7. Pale } \\
\text { triangular region around apical ocellus from costa tapering } \\
\text { posteriorly. Obscure dark submarginal band formed from these } \\
\text { contrasting regions. }\end{array}$ \\
\hline f/w apical ocellus & $\begin{array}{l}\text { Very prominent and large. Ring orange and wide }(2.4 \mathrm{~mm}) \text { and } \\
\text { colour pretty constant around whole ring. Ratio to inner black } \\
\text { ocellus approximately } 0.42 \text {. } \\
\text { Shape more round then oval. }\end{array}$ & $\begin{array}{l}\text { Not as prominent ring narrow fulvous-yellow to fulvous-orange. } \\
(1.1-1.5 \mathrm{~mm}) \text {. Colour often more obscure posteriorly. Ratio } \\
\text { to inner black ocellus approximately } 0.24 \text {. Shape more oval, } \\
\text { posteriorly more produced. }\end{array}$ \\
\hline$h / w$ tornal ocelli & $\begin{array}{l}1 \text { ocellus in space } 2 \text {. Thin reddish-ring. Black centre and central } \\
\text { white ocellus. }\end{array}$ & $\begin{array}{l}1 \text { ocellus in space } 2 \text {. Wide reddish-ring approximately half the } \\
\text { width of black centre. Central white pupil. }\end{array}$ \\
\hline h/w termen cilia & A mixture of dark brown and white appears indistinct. & White and brown tipped appears fairly prominently as a white line. \\
\hline \multicolumn{3}{|l|}{ Underside } \\
\hline ground colour & Dark chocolate brown. & $\begin{array}{l}\text { Lighter brown with more reddish and complex tones in } \mathrm{f} / \mathrm{w} \\
\text { especially around apical ocellus. }\end{array}$ \\
\hline $\begin{array}{l}\mathrm{h} / \mathrm{w} \text { white striae } \\
\text { (Image } 4 \text {, figs. } 1-2 \text { ) }\end{array}$ & $\begin{array}{l}\text { Less dense forming drifts like patterns emphasised by dark } \\
\text { brown scales. Violet tones to white striae. }\end{array}$ & $\begin{array}{l}\text { Dense and more irregular. Less contrast between white striae. } \\
\text { More yellow tones to white striae. }\end{array}$ \\
\hline apical ring & Outer reddish-red ring much narrower then orange ring. & Outer reddish-ring wider than inner fulvous-yellow ring. \\
\hline $\mathrm{h} / \mathrm{w}$ ocelli 2 and $1 \mathrm{c}$ & $\begin{array}{l}\text { Ocellus in } 2 \text { appearing } 3 x \text { the size of ocellus in } 1 c .1 c \text { blind. } \\
\text { Ring reddish-orange. }\end{array}$ & $\begin{array}{l}\text { Ocellus in } 2 \text { appearing } 2 x \text { the size as } 1 c \text {. Both ocelli with white } \\
\text { pupils. Ring fulvous-yellow. }\end{array}$ \\
\hline $\begin{array}{l}\text { white post-discal } \\
\text { ocelli h/w }\end{array}$ & $\begin{array}{l}\text { Appear to be absent, but possibly present extremely minutely } \\
\text { in space } 6 .\end{array}$ & Usually present if only minutely, but can be absent. \\
\hline
\end{tabular}

Table 2. Key identification features of male Callerebia species.

Eastern Himalayan (roughly east of Eastern Nepal) species with a large to very large ocellus that substantially occupies the apical region of the upper $\mathrm{f} / \mathrm{w}$. Ring colour usually orange fulvous but may be also be yellowish-orange to reddish. Ocellus outer rings often irregular especially when ocellus ring is wide. Under $\mathrm{h} / \mathrm{w}$ with prominent white striations overlaid with strong to weak bands and/or variegation. Often large butterflies.

These species differ significantly in wing shape from $C$. dibangensis sp. nov.: $\mathrm{f} / \mathrm{w}$ less rounded and more produced; $\mathrm{h} / \mathrm{w}$ produced and with lobe; under $\mathrm{h} / \mathrm{w}$ overlaid with bands and variegation.

\begin{tabular}{|c|c|c|}
\hline & Key identification features & Notes \\
\hline $\begin{array}{l}\text { C. polyphemus } \\
\text { C. p. annadina } \\
\text { C. p. confusa } \\
\text { C. p. ricketti }\end{array}$ & $\begin{array}{l}\text { 1. under } \mathrm{h} / \mathrm{w} \text { with basal, discal and submarginal bands, but } \\
\text { variable. Basal often absent and in ssp. annadina discal band } \\
\text { also faint. } \\
\text { 2. upper } \mathrm{f} / \mathrm{w} \text { apical ocellus reddish in C. } p \text {. annadina and C. } p \text {. } \\
\text { ricketti otherwise orange fulvous. Variable in size. If ring is wide } \\
\text { then distally distorted. } \\
\text { 3. under } \mathrm{h} / \mathrm{w} \text { tornal ocelli variable and may be absent. Always } \\
\text { absent in ssp. confusa and ssp. ricketti. } \\
\text { 4. underside white striae clearer and less dense then in C. suroia. }\end{array}$ & $\begin{array}{l}\text { A very variable butterfly. For identification of the subspecies } \\
\text { refer to Huang (2003). This is the most eastern Callerebia species } \\
\text { extending to central China. The western limit appears to be } \\
\text { eastern Tibet. Bruna et al. (2000) treat } C \text {. suroia as a western } \\
\text { subspecies and ssp. annadina as a distinct species. C. suroia may } \\
\text { overlap in northwestern Yunnan with ssp. annadina. }\end{array}$ \\
\hline $\begin{array}{l}\text { C. suroia } \\
\text { (Image 2-4, fig.3) }\end{array}$ & $\begin{array}{l}\text { 1. } \mathrm{h} / \mathrm{w} \text { basal, discal and submarginal bands very defined. } \\
\text { 2. white striation dense. } \\
\text { 3. upper } \mathrm{h} / \mathrm{w} \text { tornal ocellus usually absent. } \\
\text { 4. upper } \mathrm{f} / \mathrm{w} \text { ocellus large irregular and straight to distal margin. }\end{array}$ & $\begin{array}{l}\text { The sharply defined } \mathrm{h} / \mathrm{w} \text { bands and the irregular } \mathrm{f} / \mathrm{w} \text { ocellus } \\
\text { are very distinctive features that separate this species from all } \\
\text { other Callerebia species. Tytler (1914) remarks specimens in July } \\
\text { fresh and in August worn. Anecdotally described as woodland } \\
\text { butterfly in northwestern Yunnan. }\end{array}$ \\
\hline C. ulfi & $\begin{array}{l}\text { 1. white scales on upper } \mathrm{f} / \mathrm{w} \text { margins. } \\
\text { 2. no tornal ocelli on under } \mathrm{h} / \mathrm{w} \\
\text { 3. discal band faint. } \\
\text { 4. size smaller then C. suroia in China. }\end{array}$ & $\begin{array}{l}\text { Refer to Huang (2003) for plate, description and diagnosis. White } \\
\text { scales on upper f/w margins seem particularly diagnostic. }\end{array}$ \\
\hline $\begin{array}{l}\text { C. orixa } \\
\text { (Image 2-4, fig.5) } \\
\text { C. watsoni }\end{array}$ & $\begin{array}{l}\text { 1. under } \mathrm{h} / \mathrm{w} \text { with two tiny tornal ocelli both blind. Scales fine, } \\
\text { bands faint, but variegation strong. Ground colour reddish } \\
\text { brown. } \\
\text { 2. upper } \mathrm{f} / \mathrm{w} \text { apical ocellus orange ring round and more regular } \\
\text { then } C \text {. suroia. } \\
\text { C. watsoni similar, smaller and under } \mathrm{h} / \mathrm{w} \text { markings more } \\
\text { distinct. }\end{array}$ & $\begin{array}{l}\text { Tytler (1911) 'fairly common on grass slopes 6000-7000ft Sep- } \\
\text { Oct.' } \\
\text { Distribution and flight period July-October overlaps with C. } \\
\text { suroia in Manipur and Nagaland. }\end{array}$ \\
\hline
\end{tabular}


Eastern Himalayan species. Under $\mathrm{h} / \mathrm{w}$ with post-discal white dots (may be obscured if white striae is very heavy) and two tornal spots. Upper $\mathrm{f} / \mathrm{w}$ apical ocellus large but never occupying as much space as species above. Under $\mathrm{h} / \mathrm{w}$ pattern looks less banded. White striae fading or absent in upper submargina and discal areas.

\begin{tabular}{|l|l|l|}
\hline $\begin{array}{l}\text { C. scanda opima } \\
\text { (Image 2-4, fig.2) }\end{array}$ & $\begin{array}{l}\text { 1. upper f/w apical ocellus ring yellow/fulvous to orange. } \\
\text { 2. under h/w with dense white striae. } \\
\text { 4. under h/w lack bands and variegation. }\end{array}$ & $\begin{array}{l}\text { Much larger and more richly coloured then its nominotypical } \\
\text { form. A comparison of } C \text {. scanda opima and C. dibangensis sp. } \\
\text { nov. is presented in Table } 1 .\end{array}$ \\
\hline C. hybrida? & See western Himalayan species for note. & \\
\hline
\end{tabular}

East Himalayan species with upper $\mathrm{f} / \mathrm{w}$ apical ocelli medium to small. Ocellus not appearing to occupy a large proportion of the $\mathrm{f} / \mathrm{w}$ apical area.

C. dibangensis sp. nov. differs from these species by the size of the $\mathrm{f} / \mathrm{w}$ apical ocellus; under $\mathrm{h} / \mathrm{w}$ pattern and wing shape. $C$. baileyi and $C$. tsirava do not closely resemble any other eastern Himalayan Callerebia species.

\begin{tabular}{|c|c|c|}
\hline $\begin{array}{l}\text { C. annada annada } \\
\text { (Image 2-4, fig.6) }\end{array}$ & $\begin{array}{l}\text { 1. upper f/w apical ocellus not large but still fairly prominent, } \\
\text { almost like two separate ocelli merged together with a narrow } \\
\text { orange-fulvous ring. Hence oval shaped. } \\
\text { 2. under f/w ground colour earthy brown and reddish tones. } \\
\text { 3. under h/w white striations quite similar to } C \text {. scanda opima } \\
\text { but less white in colour. Vague discal and submarginal bands. } \\
\text { Two tornal spots with pupils. }\end{array}$ & $\begin{array}{l}\text { The nominotypical form is very rare and only from Bhutan. } \\
\text { Under } \mathrm{h} / \mathrm{w} \text { ground colour paler and much less richly coloured } \\
\text { then } C \text {. orixa and upper } \mathrm{f} / \mathrm{w} \text { ocellus much smaller. Wing shape } \\
\text { quite unlike } C \text {. dibangensis sp. nov. with termen very straight and } \\
\text { at acute angle to the costa. } \mathrm{H} / \mathrm{w} \text { produced and with lobe. }\end{array}$ \\
\hline C. baileyi & $\begin{array}{l}\text { 1. upper marginal area of both wings clouded with white scales. } \\
\text { 2. upper f/w apical ocellus not large or prominent, appearing as } \\
\text { two touching black ocelli with white pupils. Virtually no outer } \\
\text { rings to ocelli. Lower ocellus variable in size sometimes missing. } \\
\text { 3. under h/w with dense white scales making the wing appear } \\
\text { mainly white with some fine striations and quite unlike any other } \\
\text { Callerebia. }\end{array}$ & $\begin{array}{l}\text { The chalky white under } \mathrm{h} / \mathrm{w} \text {, white upper margin and rather } \\
\text { small and indistinct upper apical f/w ocellus makes this species } \\
\text { unmistakeable. Very restricted distribution: Chayu County, Tibet } \\
\text { to border of Anjaw District, Arunachal Pradesh, 1828-3048 m. } \\
\text { Recorded from } 26 \text { June-8 July. }\end{array}$ \\
\hline C. tsirava & $\begin{array}{l}\text { 1. under } \mathrm{f} / \mathrm{w} \text { reddish; apical ocellus small and round (in plate } \\
\text { lower pupil very small). } \\
\text { 2. under } \mathrm{h} / \mathrm{w} \text { dorsal and termen margins broadly covered with } \\
\text { closely-set white scales, leaving only a broad rectangular dark- } \\
\text { brown costal area. Thin wavy discal line. }\end{array}$ & $\begin{array}{l}\text { Evans (1914) states 'Closely allied to, if not a race of C. annada.' } \\
\text { Very restricted distribution: Po Chu Valley, Pemako Chung on } \\
\text { Tsang Po, 2280-2740 m. Recorded from } 30 \text { June-7 August. }\end{array}$ \\
\hline \multicolumn{3}{|c|}{$\begin{array}{l}\text { Western Himalayan species. } \\
\text { Except for } C \text {. annada caeca these are not large species. Under } \mathrm{h} / \mathrm{w} \text { white striations much weaker then the eastern Himalayan species. Upper f/w apical ocellus } \\
\text { ring narrow and never as prominent as the E. Himalayan species. No similar species to } C \text {. dibangensis sp. nov. }\end{array}$} \\
\hline C. annada caeca & $\begin{array}{l}\text { 1. under } \mathrm{h} / \mathrm{w} \text { two tornal spots blind. } \\
\text { 2. under } \mathrm{f} / \mathrm{w} \text { earth-brown slightly reddish. } \\
\text { 3. under } \mathrm{h} / \mathrm{w} \text { covered in white scales which are densest between } \\
\text { the post-discal and submarginal bands. } \\
\text { 4. larger then the other western Himalayan species. }\end{array}$ & Bruna et al. (2000) often sympatric with C. hybrida and C. scanda \\
\hline C. hybrida & $\begin{array}{l}\text { 1. under } \mathrm{h} / \mathrm{w} \text { a series of up to four white post-discal dots. } \\
\text { 2. discal and submarginal lines usually well marked but may be } \\
\text { obsolete though some indication usually appears to remain. } \\
\text { 3. white striations not so well marked and usually of very fine } \\
\text { scales (may vary according to season and region). } \\
\text { 4. under } \mathrm{h} / \mathrm{w} \text { tornal ocelli usually two with or without pupils } \\
\text { yellow/fulvous ringed. }\end{array}$ & $\begin{array}{l}\text { van der Poel \& Wangchuk (2007) have listed this species in } \\
\text { Bhutan. There is a photograph of the underside. H/w white } \\
\text { striae are denser and the } \mathrm{f} / \mathrm{w} \text { apical ocellus more orange then } \\
\text { typical. }\end{array}$ \\
\hline $\begin{array}{l}\text { C. scanda scanda } \\
\text { (Image 2-4, fig.4) }\end{array}$ & $\begin{array}{l}\text { 1. under } \mathrm{h} / \mathrm{w} \text { a series of up to four white post-discal dots. } \\
\text { 2. under } \mathrm{h} / \mathrm{w} \text { dorsal half with dense fine and white scales. Scales } \\
\text { less white and dense towards costa and apex hence giving a } \\
\text { fading effect. } \\
\text { 3. under } \mathrm{h} / \mathrm{w} \text { white scales with bluish tone. }\end{array}$ & $\begin{array}{l}\text { Ground colour much paler then } C \text {. scanda opima. It is difficult to } \\
\text { determine where } C \text {. scanda scanda ends in Nepal/Sikkim and C. } \\
\text { scanda opima begins. Specimen figured from Darjeeling, West } \\
\text { Bengal is probably the eastern limit of the nominotypical ssp. }\end{array}$ \\
\hline $\begin{array}{l}\text { C. n. nirmala } \\
\text { C. n. materta } \\
\text { C. n. daksha } \\
\text { C. n. kala } \\
\text { C. n. scandina }\end{array}$ & $\begin{array}{l}\text { 1. upper ground colour dark brown not fading distally. } \\
\text { 2. under } \mathrm{h} / \mathrm{w} 1-6 \text { post-discal ocelli and/or white dots. } \\
\text { 3. under } \mathrm{h} / \mathrm{w} \text { with/without faint discal line. } \\
\text { 4. under } \mathrm{f} / \mathrm{w} \text { ocellus round and large. } \\
\text { 5. brownish-cinereous dusting variable depending on subspecies. }\end{array}$ & Very variable with many regional subspecies. \\
\hline
\end{tabular}

5-10 km from Anini. The surrounding vegetation was mixed sub-tropical broad-leaf forest. There was no GPS available and there was no nearby habitation or named place.

\section{DISCUSSION}

This very distinctive butterfly was collected in 1987. It is possible this butterfly was overlooked for the following reasons: 
Table 3. Approximate expanse of Callerebia species

\begin{tabular}{|l|c|c|c|}
\hline & $\begin{array}{c}\text { NHM } \\
\text { collection } \\
\text { (males only) }\end{array}$ & $\begin{array}{c}\text { Huang (2003) } \\
\text { Length } \\
\text { forewing x 2 }\end{array}$ & $\begin{array}{c}\text { Talbots } \\
\text { (1947) } \\
\text { (male and } \\
\text { female) }\end{array}$ \\
\hline C. polyphemus confusa & & $70-61$ & \\
\hline C. dibangensis sp. nov. & 68 & & \\
\hline C. polyphemus & & 65 & \\
\hline C. polyphemus ricketti & & 64 & \\
\hline C. polyphemus annadina & & 62 & $76-68$ \\
\hline C. scanda opima & $62-51$ & & $70-60$ \\
\hline C. annada annada & $59-49$ & & $65-60$ \\
\hline C. suroia & $57-52$ & $65-60$ & $60-58$ \\
\hline C. orixa & $56-45$ & & $60-45$ \\
\hline C. ulfi & & 58 & $60-50$ \\
\hline C. baileyi & $56-45$ & & $67-60$ \\
\hline C. scanda & $48-39$ & & \\
\hline C. hybrida & & & \\
\hline C. tsirava & & & $60-50$ \\
\hline C. watsoni & & & \\
\hline C. nirmala & & & \\
\hline
\end{tabular}

(i) There appear to have been very few butterfly surveys of the Dibang Valley. Evans (1914) lists the butterflies collected by F.M. Bailey during his tour of southeastern Tibet. He started his trip from the Mithun Valley in mid May 1913, but does not appear to have recorded any butterflies from the region. Borang et al. (2008) conducted a survey of the Dihang-Dibang Biosphere Reserve during November 2006 and October 2007 and recorded 134 species/subspecies, but this covered many places outside of the Dibang Valley and the survey dates were probably rather late for higher elevations and they did not record any Callerebia species. Endemicity is not a feature of Himalayan butterflies, but as outlined in the introduction the Dibang Valley is in a very unique geographical zone. Two Callerebia species from neighbouring regions of Tibet - C. tsirava and $C$. baileyi appear to have very restricted distributions.

(ii) The specimen was collected at the end of July in Upper Dibang Valley. Many places such as Eaglenest (West Kameng District) have access problems in the monsoon and are consequently poorly surveyed in the months of July and August which also appears to be the main flight period for $C$. scanda opima according to the NHM collection labels.

(iii) The most surveyed areas in Arunachal Pradesh appear to be Eaglenest (West Kameng District) and Namdapha (Changlang District). Both these areas are on the outer ranges and are not an interior location where this species was collected.

C. orixa, C. annada, C. suroia, C. scanda scanda and C. scanda opima are the present known Callerebia species from northeastern India (Images 2-4). In addition an allied species Hemadara narasingha has been recorded from Sikkim, Arunachal Pradesh (Abor Hills) and the Lower Tsang Po. This species is smaller, with narrow forewings and the hindwing angled on the termen and produced at the tornus. A description may be found in Talbot (1947). I cannot find much literature regarding recent records of Callerebia in Arunachal Pradesh. Betts (1950) records C. orixa from West Kameng 'Rupa, $5000 f t$. Sept. Common in grassland in sheltered valleys in the temperate Momba country.' Older literature records two more possible Indian species. South (1914) records a specimen of $C$. polyphemus collected by F.M. Bailey at Tawang, Arunachal Pradesh. It should be noted that $C$. polyphemus has not been recorded so far west and $C$. suroia was only described in 1914 so the identification of this record needs to be confirmed. South (1913) also records that F.M. Bailey collected a specimen of C. baileyi from Dichu (6000ft, 1829m). The Dichu River, Anjaw District, Arunachal Pradesh is just before the border with Tibet. The majority of the specimens were from Drowa Gompa, Tibet $(3,048 \mathrm{~m})$ to the north of the Mishmi Hills. I have not seen any contemporary records for this species in India.

Rather speculatively I think the new species is closely allied to C. scanda opima on the basis of wing shape and the under hindwing pattern. There also appear to be minute white dots in space 6 of the under hindwing. These white dots do not appear to occur in C. polyphemus, C. suroia, C. annada and C. orixa. Bruna et al. (2000) comment that most Callerebia species are allopatric. However, the distributions of $C$. suroia and C. orixa overlap in Manipur and Nagaland, though it is not known if they fly together in the same habitat. It will be interesting to have contemporary field data and phylogenetic studies to clarify the relationships of the different forms and species.

\section{Conclusions}

Callerebia dibangensis sp. nov is a new species of Satyrine butterfly from the Dibang Valley in the eastern Himalayan region of India possibly allied to Callerebia scanda opima. I propose that this common name is determined by the people of the Dibang Valley, since this butterfly appears to be endemic to that valley. 


\section{REFERENCES}

d'Abrera, B.L. (1985). Butterflies of the Oriental region. part 2 Nymphalidae,Satyridae and Amathusidae. Melbourne: Hill House 248-534pp: col. ill; 35cm.

d'Abrera, B.L. (1990). Butterflies of the Holarctic Region. Part 1 Papilionidae, Pieridae, Danaidae and Satyridae (partim). Vic.: Hill House, 185p: col ill, maps, ports; $36 \mathrm{~cm}$.

d'Abrera, B.L. (1992). Butterflies of the Holarctic Region. Part 2 Satyridae (concl.) \& Nymphalidae (partim). Black Rock, Vic.: Hill House, 1992. xv,[3], 186-334pp: chiefly col ill, maps, port; $35 \mathrm{~cm}$.

Beccaloni, G., M. Scoble, I. Kitching, T. Simonsen, G. Robinson, B. Pitkin, A. Hine \& C. Lyal (Editors) (2003). The Global Lepidoptera Names Index (Leplndex). World Wide Web electronic publication. <http://www.nhm.ac.uk/entomology/lepindex> Online version dated 17 July 2012

Betts, F.N. (1950). On a collection of butterflies from the Balipara Frontier Tract and the Subansiri area (northern Assam). Journal of the Bombay Natural History Society 49(3): 488-502.

Bruna, C.D., E. Gallo \& V. Sbordoni (2000). Guide to the Butterflies of the Palearctic Region, Satyridae. Part 2, Subfamily Satyrinae, tribe Ypthimini: Argestina, Boeberia, Callerebia, Grumia, Hemadara, Loxerebia, Paralasa, Proterebia, Milan: Omnes Artes, 2000, 58pp

Department of Environment and Forests, Government of Arunachal (2012). Forest Statistics <http://arunachalforests.nic.in> Online version dated 12 July 2012

Evans, W.H. (1914). A list of butterflies caught by Capt.F.M Bailey in S.East Tibet during 1913. The Journal of the Bombay Natural History Society 23(1914): 532-546

Evans, W.H. (1932). The Identification of Indian Butterflies-2nd Edition. Bombay Natural History Society, Bombay, $x+454 p p+32 p l s$.

Huang, H. (1998). Research on the butterflies of the Namjagbarwa Region, S.E. Tibet Neue Entomologische Nachrichten 41: 207-264.

Huang, H. (2001). Report of H. Huang's 2000 Expedition to SE. Tibet for Rhopalocera Neue Entomologische Nachrichten 51: 65-152.

Huang (2003). A list of butterflies collected from Nujiang (Lou Tse Kiang) and Dulongiang, China with descriptions of new species, and revisional notes Neue Entomologische Nachrichten 55: 3-114.

Savela, M. (2012). Markku Savela's Lepidoptera and some other life forms - Callerebia. < ftp://www.nic.funet.fi/index/Tree_of_life/ intro.html> On-line version dated 17 July 2012

South, R. (1913). A list of butterflies collected by Captain F.M. Bailey in western China, south-eastern Tibet, and the Mishmi Hills, 1911 Journal of the Bombay Natural History Society 22(2): 345-365, (3): 598-615.

Talbot, G. (1947). Fauna of British India. Butterflies Volume 2. Community online edition <http://archive.org/details/ FaunaOfBritishIndia.Butterflies2> pp. 298-315. Online version dated 02 August 2012

Tytler, H.C. (1911). Notes on the Butterflies of the Naga Hills - Part 1. Journal of the Bombay Natural History Society 21(1): 48-65.

Tytler, H.C. (1914-1915). Notes on some new and interesting butterflies from Manipur and the Naga Hills Part 1-3. Journal of the Bombay Natural History Society 23(2): 216-229 (1914), 23(3): 502-515, pl.1-2 (1915), 24(1): 119-155, pl.3-4 (1915)

Upper Dibang Valley official website (2012). Dibang Valley District at a Glance <http://dibangvalley.nic.in/> Online version dated 12 July 2012.

van der Poel, P. \& T. Wangchuk (2007). Butterflies of Bhutan Mountains, hills and valleys between 800 and $3000 \mathrm{~m}$. Royal Society for Protection of Nature (RSPN). Thimphu, Bhutan.

Wynter-Blyth, M.A. (1957). Butterflies of the Indian Region. Bombay Natural History Society, Bombay, $x x+523 p p+72 p l$
Appendix 1. List of Callerebia species and subspecies. (based on Bruna et al. (2000), Huang (2003) and Savela (2012).

\section{Callerebia annada (Moore, 1858)}

C. a. annada (Moore, 1858) Bhutan

C. a. caeca (Watkins, 1925) Kashmir to Nepal

2. Callerebia baileyi (South, 1913)

C. b. baileyi (South, 1913) Chayu county, E. Tibet, Anjaw

District, Arunachal Pradesh?

3. Callerebia hybrida (Butler, 1880)

C. h. hybrida (Butler, 1880), Himachal Pradesh - Nepal, Bhutan?

4. Callerebia nirmala (Moore, 1865)

C. n. nirmala (Moore, 1865) Kangra District, Himachal Pradesh to W. Nepal

C. n. materta (Fruhstorfer, 1916) Chitral

C. n. daksha (Moore, 1874) Kashmir

C. n. kala (Evans, 1924) Muree, Pakistan

C. n. scandina (Fruhstorfer, 1916) Kinnaur district, Himachal

Pradesh (Bashahr and Kunawur)

5. Callerebia orixa (Moore, 1872)

C. o. orixa (Moore, 1872) Meghalaya, Manipur, Nagaland, N.

Thailand? Laos?

6. Callerebia polyphemus (Oberthür, 1877)

C. p. polyphemus (Oberthür, 1877) S. Gansu, S. Ghanxi, W. Sichuan

C. p. annadina (Watkins, 1927) N.W. Yunnan

C. p. confusa (Watkins, 1925) Hubei, Hunan

C. p. ricketti (Watkins, 1925) Fujian S.W. China

7. Callerebia scanda (Kollar, 1844)

C. s. scanda (Kollar, 1844) Kashmir to S. Sikkim, Darjeeling, West Bengal

C. s. opima (Watkins, 1927) Eastern Nepal N. Sikkim, E. Bhutan 8. Callerebia suroia (Tytler, 1914)

C. s. suroia (Tytler, 1914) Manipur, Nagaland, N. Myanmar, N.

Yunnan, Sichuan, N. Vietnam

9. Callerebia tsirava (Evans, 1915)

C. tsirava (Evans, 1915) S.E. Tibet (Po Chu Valley, Pemako Chung on Tsang Po)

Note publication dates seems to be 1914 .

10. Callerebia ulfi (Huang, 2003)

C. ulfi (Huang, 2003) N.W. Yunnan

11. Callerebia watsoni (Watkins, 1925)

C. watsoni (Watkins, 1925) Chin Hills, Myanmar 